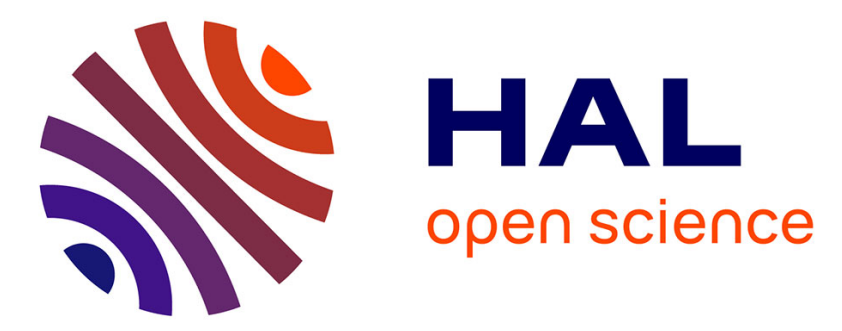

\title{
Na6Si2O7 - the missing structural link among alkali pyrosilicates
}

\author{
Volker Kahlenberg, Thomas Langreiter, Erik Arroyabe
}

\section{To cite this version:}

Volker Kahlenberg, Thomas Langreiter, Erik Arroyabe. Na6Si2O7 - the missing structural link among alkali pyrosilicates. Journal of Inorganic and General Chemistry / Zeitschrift für anorganische und allgemeine Chemie, 2010, 636 (11), pp.1974. 10.1002/zaac.201000120 . hal-00552471

\section{HAL Id: hal-00552471 https://hal.science/hal-00552471}

Submitted on 6 Jan 2011

HAL is a multi-disciplinary open access archive for the deposit and dissemination of scientific research documents, whether they are published or not. The documents may come from teaching and research institutions in France or abroad, or from public or private research centers.
L'archive ouverte pluridisciplinaire HAL, est destinée au dépôt et à la diffusion de documents scientifiques de niveau recherche, publiés ou non, émanant des établissements d'enseignement et de recherche français ou étrangers, des laboratoires publics ou privés. 


\section{Zeitschrift für Anorganische und}

Allgemeine Chemie

\section{Na6Si207 - the missing structural link among alkali pyrosilicates}

\begin{tabular}{|c|c|}
\hline Journal: & Zeitschrift für Anorganische und Allgemeine Chemie \\
\hline Manuscript ID: & zaac. 201000120.R1 \\
\hline Wiley - Manuscript type: & Article \\
\hline $\begin{array}{r}\text { Date Submitted by the } \\
\text { Author: }\end{array}$ & 13-Apr-2010 \\
\hline Complete List of Authors: & $\begin{array}{l}\text { Kahlenberg, Volker; University of Innsbruck, Institute of Mineralogy } \\
\text { and Petrography } \\
\text { Langreiter, Thomas; University of Innsbruck, Institute of Mineralogy } \\
\text { and Petrography } \\
\text { Arroyabe, Erik; University of Innsbruck, Institute of Mineralogy and } \\
\text { Petrography }\end{array}$ \\
\hline Keywords: & Na6Si207, sodium pyrosilicate, sorosilicate, twinning \\
\hline
\end{tabular}

\section{S ScholaroNE \\ Manuscript Central}


1

3

4

5

6

7

8

9

10

11

12

13

14

15

16

17

18

19

20

21

$\mathrm{Na}_{6} \mathrm{Si}_{2} \mathrm{O}_{7}$ - the missing structural link among alkali pyrosilicates

V. Kahlenberg ${ }^{\mathrm{a}}$, T. Langreiter ${ }^{\mathrm{a}}$ and E. Arroyabe ${ }^{\mathrm{a}}$

${ }^{a}$ Innsbruck/Austria, Institute of Mineralogy and Petrography, University of Innsbruck,

*Prof. Dr. Volker Kahlenberg

Institut für Mineralogie und Petrographie

Leopold-Franzens-Universität Innsbruck

Innrain 52

A - 6020 Innsbruck

Tel.: +43(0)5125075503 ; FAX: +43(0)5125072926

E-Mail: Volker.Kahlenberg@uibk.ac.at 


\begin{abstract}
The crystal structure of sodium pyrosilicate $\left(\mathrm{Na}_{6} \mathrm{Si}_{2} \mathrm{O}_{7}\right)$ has been solved from single crystal diffraction data and refined to an $R$-index of 0.051 for 17034 independent reflections. The compound is triclinic with space group $P \overline{1}(a=5.8007(8) \AA, b=11.5811(15) \AA, c=$ 23.157(3) $\AA, \alpha=89.709(10)^{\circ}, \beta=88.915(11)^{\circ}, \gamma=89.004(11)^{\circ}, V=1555.1(4) \AA^{3}, Z=8, \mathrm{D}_{\mathrm{x}}=$ $\left.2.615 \mathrm{~g} / \mathrm{cm}^{3}, \mu\left(\mathrm{Mo} K_{\alpha}\right)=7.94 \mathrm{~cm}^{-1}\right)$. A characteristic feature of the crystals is a twinning by reticular pseudo-merohedry, simulating a much larger monoclinic $C$-centered lattice $\left(V^{\prime}=\right.$ $6220 \AA^{3}, Z=32$ ). The twin element corresponds to a twofold rotation axis running parallel to the $\left[\begin{array}{lll}0 & -2 & 1\end{array}\right]$ direction of the triclinic cell. The compound belongs to the group of sorosilicates, i.e. it is based on $\left[\mathrm{Si}_{2} \mathrm{O}_{7}\right]$-groups, which are arranged in layers parallel to (100). Charge compensation within the structure is accomplished by monovalent $\mathrm{Na}$ cations distributed among 24 crystallographically independent positions. They are coordinated by four to six nearest oxygen neighbors. Most of the coordination polyhedra can be approximately described as distorted tetrahedra or tetragonal pyramids. An alternative understanding of $\mathrm{Na}_{6} \mathrm{Si}_{2} \mathrm{O}_{7}$ can be gained if the tetrahedrally coordinated sodium atoms are considered for the construction of a framework. Actually, each four of the dimers within a single slice are linked by a more or less distorted $\left[\mathrm{NaO}_{4}\right]$-tetrahedron. The resulting structural motif is similar to the one that can be observed in melilites, where linkage between the $\mathrm{T}_{2} \mathrm{O}_{7}$ ( $\mathrm{T}: \mathrm{Al}, \mathrm{Si}$ ) moieties is provided by $\left[\mathrm{MgO}_{4}\right]$ - (as in akermanite, $\mathrm{Ca}_{2} \mathrm{Mg}\left[\mathrm{Si}_{2} \mathrm{O}_{7}\right]$ ) or $\left[\mathrm{AlO}_{4}\right]$-tetrahedra (as in gehlenite, $\mathrm{Ca} 2 \mathrm{Al}\left[\mathrm{AlSiO}_{7}\right]$ ). By sharing common edges, the $\left[\mathrm{NaO}_{4}\right]$-tetrahedra in $\mathrm{Na}_{6} \mathrm{Si}_{2} \mathrm{O}_{7}$ are forming columns running parallel to [100]. The resulting framework contains tunnels in which the more irregularly coordinated sodium cations are incorporated.
\end{abstract}

Keywords : $\mathrm{Na}_{6} \mathrm{Si}_{2} \mathrm{O}_{7}$, sodium pyrosilicate, sorosilicate, twinning 


\section{Introduction}

Sodium silicates have been studied intensively in the past since they are of special interest for certain areas of industrial inorganic chemistry and technical mineralogy. Fields of applications include, for example, production of water glass solutions, ion exchangers and builders in washing powders, making of acid-resistant enamel frits or components of refractory cements as well as inorganic binders - just to mention a few. Therefore, it is not surprising that the phase diagram $\mathrm{Na}_{2} \mathrm{O}-\mathrm{SiO}_{2}$ has been investigated frequently. Concurrently, Kracek [1] as well as D'Ans \& Löffler [2] reported results on the phase relationships in the alkali-rich part of this binary system. However, their observations concerning the number of crystalline phases and their melting behaviour were contradictory. Whereas D'Ans \& Löffler mentioned the occurrence of a congruently melting silicate with composition $3 \mathrm{Na}_{2} \mathrm{O} \cdot 2 \mathrm{SiO}_{2}$ (melting point: $1115^{\circ} \mathrm{C}$ ), Kracek could not find any evidence for this so-called 3:2 phase. However, several later investigations [3-7] undoubtedly proved the existence of the compound $\mathrm{Na}_{6} \mathrm{Si}_{2} \mathrm{O}_{7}$.

First basic structural data including a powder diffraction pattern as well as a proposal for the unit cell parameters for sodium pyrosilicate were given by Kautz, Müller \& Schneider [8]. Moreover, the same authors reported that $\mathrm{Na}_{6} \mathrm{Si}_{2} \mathrm{O}_{7}$ has a lower stability of about $620^{\circ} \mathrm{C}$ where it decomposes into $\mathrm{Na}_{2} \mathrm{Si}_{2} \mathrm{O}_{5}$ and $\mathrm{Na}_{4} \mathrm{SiO}_{4}$ but that it can be preserved at ambient conditions by quenching from higher temperatures.

In summary one can say, that eighty years after its first description in this journal and forty years after a preliminary crystallographic characterization a detailed structural investigation of sodium pyrosilicate is still missing. In the course of a long-term project aiming on the elucidation of the phase equilibria and the crystal chemistry of alkali silicates, we decided to study the crystal structure of $\mathrm{Na}_{6} \mathrm{Si}_{2} \mathrm{O}_{7}$ in more detail.

\section{Experimental details}

So far, successful synthesis experiments of sodium pyrosilicate were based on the following approaches: (a) conversion of $\mathrm{Na}_{2} \mathrm{SiO}_{3}-\mathrm{NaOH}$ mixtures $[2,8]$ (b) reaction between $\mathrm{Na}_{2} \mathrm{O}_{2}$ and $\mathrm{SiO}_{2}$ [8] and (c) thermal decomposition of $\mathrm{Na}_{3}\left(\mathrm{HSiO}_{4}\right) \cdot 5 \mathrm{H}_{2} \mathrm{O}$ [9]. Since $\mathrm{Na}_{6} \mathrm{Si}_{2} \mathrm{O}_{7}$ has been reported to melt congruently at about $1115^{\circ} \mathrm{C}$ [2] we decided to grow 
single crystalline material directly from the melt. Starting materials for our own preparations were $\mathrm{Na}_{2} \mathrm{CO}_{3}$ (Merck, p.a.) and $\mathrm{SiO}_{2}$ (quartz, Alfa Aesar, 99.995\%). The educts for $2 \mathrm{~g}$ of a stoichiometric mixture were homogenized in a planetary mill for 45 minutes under ethanol, dried at $60^{\circ} \mathrm{C}$, placed into a platinum crucible, covered with a lid and transferred to a resistance heated furnace. The samples were fired from $300^{\circ} \mathrm{C}$ to $1200^{\circ} \mathrm{C}$ with a heating rate of $100^{\circ} \mathrm{C} / \mathrm{h}$, held at the final temperature for 2 hours, subsequently cooled with $10^{\circ} \mathrm{C} / \mathrm{h}$ to $700^{\circ} \mathrm{C}$ and finally quenched in air. A first inspection of the run product was based on light microscopy as well as X-ray powder diffraction. As known from previous investigations, sodium pyrosilicate is very hygroscopic. Therefore, after removing of the crucible from the furnace, the part of the sample which was intended to be used for the microscopic studies and the selection of single crystals was immediately covered with inert oil (Paratone-N, Hampton Research). For the same reason, the preparation for the $\mathrm{X}$-ray powder diffraction samples including grinding of the material and filling of the glass capillaries $(0.3 \mathrm{~mm}$ diameter $)$ was performed in a glove bag under an argon atmosphere. The optical investigations using a polarizing microscope proved the yield to be a mixture of two crystalline phases. A smaller amount of platy, lowbirefringent crystals with well developed faces (phase 1) occurred along with large irregularly shaped crystals of high birefringence showing polysynthetic twinning (phase 2). The powder diffraction pattern collected on a STOE STADI-MP diffractometer operated in transmission geometry indicated $\mathrm{Na}_{6} \mathrm{Si}_{2} \mathrm{O}_{7}$ (Powder Diffraction File (PDF-2), entry no. 27-0784) to be the main phase (= phase 2) of the synthesis run. Furthermore, sodium metasilicate (PDF-2 entry 16-0818) could be detected (corresponding to phase 1). The presence of $\mathrm{Na}_{2} \mathrm{SiO}_{3}$ was surprising because the initial mixture had a $\mathrm{Na}_{2} \mathrm{O}: \mathrm{SiO}_{2}$ ratio of $3: 2$. We attribute this finding to a potential evaporation loss of sodium during the crystal growth experiment.

Structural investigations of single crystalline $\mathrm{Na}_{6} \mathrm{Si}_{2} \mathrm{O}_{7}$ were performed on an Oxford Diffraction Gemini R Ultra single crystal diffractometer using Mo- $\mathrm{K}_{\alpha}$ radiation. Therefore, optically pre-selected crystals were mounted on the tip of a glass fiber with nail hardener. Almost twenty crystals were screened by short data collections revealing the low overall diffraction quality of the samples. In addition to the already mentioned twinning 
phenomena almost all crystals exhibited radial smearing of the reflections. For the final data collection a twinned crystal with comparatively sharp diffraction spots was selected. Acquisition of the intensities was accomplished at $-25^{\circ} \mathrm{C}$ using a nitrogen stream generated by an Oxford Cryostream 700-series cooler. Flushing the crystal in dried nitrogen successfully prevented the decay of the hygroscopic material during the data collection. Processing of the data with the CrysAlisPro software package indicated the "single crystal" to be an intergrowth of one prominent (I) and two minor (II,III) individuals which all three could be indexed with a pseudo-tetragonal, monoclinic $C$-centered cell, similar to the one that had been already proposed by Kautz et al. [8]: $a^{\prime}=32.84 \AA, b^{\prime}=32.67 \AA, c^{\prime}=$ $5.80 \AA, \beta^{\prime}=91.47^{\circ}$. Due to the low absorption coefficient of the material for Mo-K $\mathrm{K}_{\alpha}$ radiation $\left(\mu=0.794 \mathrm{~mm}^{-1}\right)$ no absorption correction has been performed. Scattering curves for neutral atoms, together with anomalous dispersion corrections, were taken from the International Tables for Crystallography, Volume $C$ [10]. However, structure solution by direct methods with the non-overlapping data belonging to component $\mathrm{I}$ in all possible monoclinic $C$-centered space groups corresponding to the extinction symbol $2 / m \mathrm{C} 1-1$ failed (program SIR2002 [11]).

A thorough investigation of precession-type reconstructions of reciprocal space disclosed that the diffraction pattern of the large $C$-centered cell can be explained by superposition/twinning of two much smaller triclinic cells with the following lattice parameters: $a=5.8007 \AA, b=11.5811 \AA, c=23.157 \AA, \alpha=89.709^{\circ}, \beta=88.915^{\circ}, \gamma=89.004^{\circ}$ $\left(\mathrm{V}=1555 \AA^{3}\right)$. The twin element corresponds to a twofold rotation axis running parallel to the $\left[\begin{array}{lll}0 & -2 & 1\end{array}\right]$ direction of the triclinic cell. The primed and unprimed basis vectors of the small and the large cells are related via the following transformation: $\mathbf{a}^{\prime}=\mathbf{2} \mathbf{b}+\mathbf{c}, \mathbf{b}^{\prime}=\mathbf{2} \mathbf{b}-\mathbf{c}$ and $\mathbf{c}^{\prime}=-\mathbf{a}$. In summary one can say that each of the three domains within the "single crystal" in turn consists of two twin individuals related by reticular pseudo-merohedry. In the next step, the data of the largest domain I were re-processed in order to produce two data sets Ia and Ib including only the non-overlapping reflections (for structure solution) as well as a third data set containing the specific twin information, i.e. the overlapping as well as the non-overlapping reflections (so-called HKLF5 format) for the subsequent refinement. Structure determination with data set Ia using direct methods resulted in a 
crystallochemically reasonable model showing the expected number of $\left[\mathrm{SiO}_{4}\right]$-tetrahedra as well as most of the sodium atoms. After completing the structure by difference Fourier calculations (program SHELX97 [12]), subsequent least squares refinements with isotropic displacement parameters converged to a residual of $R(|F|)=0.208$. Taking the twin model into consideration improved the calculations substantially $(R(|F|)=0.059,242$ parameters). The introduction of anisotropic displacement parameters for all atoms, however, lowered the residual index only slightly $(\mathrm{R}(|\mathrm{F}|=0.039,543$ parameters $)$ and resulted in a nonpositive definite temperature factor of the oxygen atom O5. A re-examination of the diffraction data as well as of the crystal structure using the MISSYM algorithm implemented in the PLATON program suite [13] did not reveal any indication that a wrong space group symmetry had been chosen nor did we detect any evidence for a systematic error in the data reduction. We attribute the problem with the thermal motion of the oxygen atom $\mathrm{O} 5$ to the generally lower quality of the twinned data set relative to the diffraction data which can be gained from a good single crystal. The final atomic coordinates of the calculations with anisotropic temperature factors for the $\mathrm{Si}$ and $\mathrm{Na}$ atoms as well as selected bond distances and angles are given in Table 2, 3 and 4 respectively. Crystallographic data for the structure reported here have been deposited with the Fachinformationszentrum Karlsruhe, D-76344 Eggenstein-Leopoldshafen, Germany (crysdata@FIZ-Karlsruhe.de), and are available on quoting the deposition number 421643.

Using the structure models for $\mathrm{Na}_{6} \mathrm{Si}_{2} \mathrm{O}_{7}$ as well as for $\mathrm{Na}_{2} \mathrm{SiO}_{3}$ [14] a quantitative phase analysis based on the Rietveld method was performed. The two-phase refinement confirmed that sodium pyrosilicate is the dominant crystalline compound $(67.3 \mathrm{wt} . \%)$ in the sample.

\section{Results and discussion}

As may be anticipated from the chemical formula, $\mathrm{Na}_{6} \mathrm{Si}_{2} \mathrm{O}_{7}$ belongs to the group of sorosilicates, i.e. the material is based on $\left[\mathrm{Si}_{2} \mathrm{O}_{7}\right]$-groups. In more detail, a total of four crystallographically independent bitetrahedral units occupying general positions have to be distinguished. As shown in Figure 1a, the tetrahedra are arranged in layers parallel to 
(100). Charge compensation within the structure is accomplished by monovalent $\mathrm{Na}-$ cations, which are distributed among a total of 24 crystallographically independent positions.

The Si-O bond distances within the dimers show a considerable spread, ranging between 1.590-1.685 A. However, the observed variation follows the expected trend for $\left[\mathrm{Si}_{2} \mathrm{O}_{7}\right]-$ groups having one bridging and three terminal atoms: the distances between the silicon atoms and the terminal oxygens are considerably shorter (average: $1.614 \AA$ ) than the corresponding bond length to the bridging oxygens $\mathrm{O}(4), \mathrm{O}(11), \mathrm{O}(18)$ and $\mathrm{O}(25)$ (average: $1.673 \AA$ ). The shortening of the $\mathrm{Si}-\mathrm{O}_{\text {term }}$ bond lengths (by an average of $0.059 \AA$ ) results from the stronger attraction between $\mathrm{O}$ and $\mathrm{Si}$ than between $\mathrm{O}$ and the sodium cations in the structure. The distortion is also reflected in the $\mathrm{O}-\mathrm{Si}-\mathrm{O}$ angles ranging from $101.9^{\circ}$ to $115.7^{\circ}$, respectively. Nevertheless, the mean $<\mathrm{O}-\mathrm{Si}-\mathrm{O}>$ angles are close to the ideal value for an undistorted tetrahedron. The tetrahedral distortion can be expressed numerically via the quadratic elongations (Q.E.) and the angle variances (A.V.) [15], the values of which are listed in Table 3. Geometrically, the four $\left[\mathrm{Si}_{2} \mathrm{O}_{7}\right]^{6-}$ anions are in a staggered conformation. The Si-O-Si bond angles are not linear but adopt significantly smaller values between 141.3 and $148.1^{\circ}$.

The sodium positions are coordinated by four to six nearest oxygen neighbors. Most of the coordination polyhedra can be approximately described as distorted tetrahedra or tetragonal pyramids. The $\mathrm{NaO}_{\mathrm{n}}$-polyhedra are joined by corner- or edge-sharing.

Calculation of the bond valence sums (BVS) using the parameters for the $\mathrm{Na}-\mathrm{O}$ and $\mathrm{Si}-\mathrm{O}$ bonds given by Brese \& O'Keeffe [16] indicated a satisfactory agreement with the expected values of +1 v.u. (for $\mathrm{Na}$ ), +4 v.u. (for $\mathrm{Si}$ ) and -2 v.u. (for $\mathrm{O}$ ), respectively (see Table 2). For a numerical expression of the lattice strain within the structure the "global instability index" GII [17] can be used:

$$
\mathrm{GII}=\sqrt{\frac{\sum_{\mathrm{i}} \Delta_{\mathrm{i}}^{2}}{\mathrm{~N}}}
$$

$\Delta_{\mathrm{i}}$ represents the difference between the formal oxidation state for atom $\mathrm{i}$ and its bond valence sum, while $\mathrm{N}$ is the number of atoms in the asymmetric unit. Therefore, this parameter measures the extent to which the valence sum rule is violated. According to 
Brown [18] values of GII less than 0.05 v.u. suggest that little or no lattice strain is present while values greater than $0.20 \mathrm{v} . \mathrm{u}$. indicate a structure that is so strained to be unstable. The observed GII value of 0.10 at quasi ambient conditions shows that some lattice strain is present but that it is not very pronounced.

The crystal structures of the three isotypic compounds $\mathrm{K}_{6} \mathrm{Si}_{2} \mathrm{O}_{7}$ [19], $\mathrm{Rb}_{6} \mathrm{Si}_{2} \mathrm{O}_{7}$ and $\mathrm{Cs}_{6} \mathrm{Si}_{2} \mathrm{O}_{7}$ [20] as well as of $\mathrm{Li}_{6} \mathrm{Si}_{2} \mathrm{O}_{7}$ [21] have been already determined, i.e. $\mathrm{Na}_{6} \mathrm{Si}_{2} \mathrm{O}_{7}$ was the missing structural link among this group of sorosilicates. Projections of the alignments of the anion complexes given in Figure 1 underline the close relationship between the alkali pyrosilicates on the one hand and the so-called modification II of $\mathrm{Ag}_{6} \mathrm{Si}_{2} \mathrm{O}_{7}$ [22]. All structures can be cut into slices where the $\left[\mathrm{Si}_{2} \mathrm{O}_{7}\right]$-moieties adopt a (pseudo)quadratic pattern. The Si-Si vectors of the bitetrahedral groups in neighboring slices are rotated about $90^{\circ}$ against each other. Therefore, an ...ABAB... stacking sequence is produced which generates a characteristic zig-zag pattern that is apparent in Figure 1. However, it has to be emphasized that this herringbone type pattern of the dimers is not restricted to silicates, but occurs also, for example, in pyrogermanates $\left(\mathrm{K}_{6} \mathrm{Ge}_{2} \mathrm{O}_{7}\right.$ and $\left.\mathrm{Rb}_{6} \mathrm{Ge}_{2} \mathrm{O}_{7},[23]\right)$, titanates $\left(\mathrm{K}_{6} \mathrm{Ti}_{2} \mathrm{O}_{7},[24]\right)$ or cobaltates(IV) $\left(\mathrm{K}_{6} \mathrm{Co}_{2} \mathrm{O}_{7}\right.$, [25]). Structural differences between the above mentioned silicates can be mainly attributed to (a) the conformation of the dimers and/or (b) linkage between the corner sharing double-tetrahedra and monovalent cations.

An alternative understanding of the structure of $\mathrm{Na}_{6} \mathrm{Si}_{2} \mathrm{O}_{7}$ can be gained if the tetrahedrally coordinated sodium atoms are considered for the construction of a framework. Actually, each four of the dimers within a single slice are linked by a more or less distorted $\left[\mathrm{NaO}_{4}\right]$-tetrahedron. The resulting structural motif is similar to the one which can be observed in melilites where linkage between the $\mathrm{T}_{2} \mathrm{O}_{7}(\mathrm{~T}: \mathrm{Al}, \mathrm{Si}$ ) moieties is provided by $\left[\mathrm{MgO}_{4}\right]-$ (as in akermanite, $\mathrm{Ca}_{2} \mathrm{Mg}\left[\mathrm{Si}_{2} \mathrm{O}_{7}\right]$ ) or $\left[\mathrm{AlO}_{4}\right]$-tetrahedra (as in gehlenite, $\left.\mathrm{Ca} 2 \mathrm{Al}\left[\mathrm{AlSiO}_{7}\right]\right)$. By sharing of common edges, the $\left[\mathrm{NaO}_{4}\right]$-tetrahedra in $\mathrm{Na}_{6} \mathrm{Si}_{2} \mathrm{O}_{7}$ are forming columns running parallel to [100]. The resulting framework contains tunnels in which the more irregularly coordinated sodium cations are incorporated (see Figure 2). 


\section{Conclusion}

Finally, we would like make some comments concerning the hygroscopicity of sodium pyrosilicate. One may be tempted to argue that in very hygroscopic crystalline materials the bond valence sum rule may not be fulfilled for certain cations or anions and that the strongly underbonded sites could be the sources which attract moisture from the air. However, the calculation of the individual bond valence sums did not indicate any spectacular deviations from the expected formal valences, i.e. the cations and anions are locally charge balanced. On the other hand, the mean coordination of sodium in $\mathrm{Na}_{6} \mathrm{Si}_{2} \mathrm{O}_{7}$ equals to 4.75 , whereas the "ideal" coordination number of Na has a value of 6. [17], i.e. the coordination environments for the sodium cations are far from ideal and, therefore, $\mathrm{Na}_{6} \mathrm{Si}_{2} \mathrm{O}_{7}$ is unstable with respect to the formation of other compounds in which the alkali cations can adopt more favorable surroundings.

\section{Acknowledgement}

The authors are thankful to Dr. Herwig Schottenberger (Institute of General, Inorganic and Theoretical Chemistry, University of Innsbruck) for his support with the preparation steps under inert gas atmosphere as well as to two anonymous referees for their helpful comments and suggestions. 
Table 1. Crystal data and structure refinement for $\mathrm{Na}_{6} \mathrm{Si}_{2} \mathrm{O}_{7}$.

Empirical formula

Formula weight

Temperature

Wavelength

Crystal system, space group

Unit cell dimensions

Volume

Z, Calculated density

Absorption coefficient

$\mathrm{F}(000)$

Crystal size

Theta range for data collection

Limiting indices

Reflections collected / unique

Absorption correction

Refinement method

Data / restraints / parameters

Observed Reflections $[\mathrm{I}>2 \sigma(\mathrm{I})]$

Goodness-of-fit on $\mathrm{F}^{2}$

Final R indices $[\mathrm{I}>2 \sigma(\mathrm{I})]$

$\mathrm{R}$ indices (all data)

Largest diff. peak and hole
$\mathrm{Na}_{6} \mathrm{Si}_{2} \mathrm{O}_{7}$

306.11

248(2) K

$0.71073 \AA$

triclinic, $\mathrm{P} \overline{1}$

$\mathrm{a}=5.8007(8) \AA$

$\mathrm{b}=11.5811(15) \AA$

$\mathrm{c}=23.157(3) \AA$

$\alpha=89.709(10)^{\circ}$

$\beta=88.915(11)^{\circ}$

$\gamma=89.004(11)^{\circ}$

1555.1(4) $\AA^{3}$

$8,2.615 \mathrm{~g} / \mathrm{cm}^{3}$

$0.794 \mathrm{~mm}^{-1}$

1200

$0.12 \times 0.19 \times 0.26 \mathrm{~mm}$

3.17 to $28.55 \mathrm{deg}$.

$-7<=\mathrm{h}<=7,-15<=\mathrm{k}<=15,-31<=\mathrm{l}<=30$

17034 / 17034

None

Full-matrix least-squares on $\mathrm{F}^{2}$

17034 / 0 / 402

10069

0.958

$\mathrm{R} 1=0.0510, \mathrm{wR} 2=0.1370$

$\mathrm{R} 1=0.0761, \mathrm{wR} 2=0.1515$

0.838 and $-0.753 \mathrm{e} / \AA^{-3}$ 
Table 2. Atomic coordinates ( $\left.\times 10^{4}\right)$, equivalent isotropic displacement parameters $\left(\AA^{2} \times 10^{3}\right)$ as well as bond valence sums (BVS) for $\mathrm{Na}_{6} \mathrm{Si}_{2} \mathrm{O}_{7}$. $\mathrm{U}_{\text {eq }}$ is defined as one third of the trace of the orthogonalized $U_{\mathrm{ij}}$ tensor. Oxygen atoms have been refined isotropically.

\begin{tabular}{|c|c|c|c|c|c|}
\hline & $x$ & Y & z & $\mathrm{U}_{\mathrm{eq}} / \mathrm{U}_{\text {iso }}$ & BVS \\
\hline Si (1) & $5573(3)$ & $7461(2)$ & $1845(1)$ & $9(1)$ & 3.886 \\
\hline Si (2) & $4392(3)$ & $7506(2)$ & $518(1)$ & $8(1)$ & 4.012 \\
\hline Si (3) & $-630(4)$ & $1082(2)$ & $1321(1)$ & $9(1)$ & 3.920 \\
\hline Si (4) & $617(4)$ & $3713(2)$ & $1243(1)$ & $8(1)$ & 3.987 \\
\hline Si (5) & $4415(3)$ & $2521(2)$ & $3155(1)$ & $9(1)$ & 3.984 \\
\hline Si (6) & $5663(4)$ & $2461(2)$ & $4492(1)$ & $9(1)$ & 3.990 \\
\hline Si (7) & $10606(4)$ & $8743(2)$ & $3740(1)$ & $8(1)$ & 3.959 \\
\hline Si (8) & $9345(3)$ & $6059(2)$ & $3700(1)$ & $9(1)$ & 3.959 \\
\hline $\mathrm{Na}(1)$ & $7540(5)$ & $9912(2)$ & $2375(1)$ & $14(1)$ & 0.993 \\
\hline $\mathrm{Na}(2)$ & $6209(5)$ & $183(2)$ & $3765(1)$ & $15(1)$ & 0.989 \\
\hline $\mathrm{Na}(3)$ & $2517(5)$ & $65(2)$ & $2721(1)$ & $17(1)$ & 0.964 \\
\hline $\mathrm{Na}(4)$ & $3643(4)$ & $9753(2)$ & $1404(1)$ & $17(1)$ & 1.110 \\
\hline $\mathrm{Na}(5)$ & $2467(5)$ & $5250(2)$ & $73(1)$ & $14(1)$ & 1.131 \\
\hline $\mathrm{Na}(6)$ & $7478(5)$ & $380(2)$ & $5054(1)$ & $15(1)$ & 0.998 \\
\hline $\mathrm{Na}(7)$ & $7429(5)$ & $5260(2)$ & $2505(1)$ & $16(1)$ & 0.915 \\
\hline $\mathrm{Na}(8)$ & $6106(5)$ & $5030(2)$ & $1223(1)$ & $17(1)$ & 0.877 \\
\hline $\mathrm{Na}(9)$ & $1189(5)$ & $7408(2)$ & $2533(1)$ & $15(1)$ & 0.952 \\
\hline $\mathrm{Na}(10)$ & $2446(5)$ & $5094(2)$ & $5060(1)$ & $14(1)$ & 0.977 \\
\hline $\mathrm{Na}(11)$ & $7526(5)$ & $178(2)$ & $-1(1)$ & $16(1)$ & 0.907 \\
\hline $\mathrm{Na}(12)$ & $1206(4)$ & $2736(2)$ & $121(1)$ & $20(1)$ & 1.007 \\
\hline $\mathrm{Na}(13)$ & $6069(4)$ & $7883(2)$ & $3131(1)$ & $15(1)$ & 0.944 \\
\hline $\mathrm{Na}(14)$ & $8922(5)$ & $2508(2)$ & $2477(1)$ & $17(1)$ & 0.836 \\
\hline $\mathrm{Na}(15)$ & $2503(5)$ & $4715(2)$ & $2355(1)$ & $16(1)$ & 1.170 \\
\hline $\mathrm{Na}(16)$ & $1409(5)$ & $2311(2)$ & $5170(1)$ & $16(1)$ & 1.076 \\
\hline $\mathrm{Na}(17)$ & $5678(4)$ & $2369(2)$ & $763(1)$ & 21 ( 1 ) & 0.946 \\
\hline $\mathrm{Na}(18)$ & $8952(4)$ & $8479(2)$ & $1022(1)$ & $20(1)$ & 0.957 \\
\hline $\mathrm{Na}(19)$ & $4171(4)$ & $2173(2)$ & $1952(1)$ & $16(1)$ & 0.932 \\
\hline $\mathrm{Na}(20)$ & $3823(5)$ & $4795(2)$ & $3604(1)$ & $20(1)$ & 0.963 \\
\hline $\mathrm{Na}(21)$ & $885(4)$ & $6205(2)$ & $1307(1)$ & $18(1)$ & 0.841 \\
\hline $\mathrm{Na}(22)$ & $1045(4)$ & $1250(2)$ & $4006(1)$ & $16(1)$ & 0.978 \\
\hline $\mathrm{Na}(23)$ & $3972(4)$ & $7069(2)$ & $4215(1)$ & $22(1)$ & 0.926 \\
\hline $\mathrm{Na}(24)$ & $9230(4)$ & $3540(2)$ & $3760(1)$ & 21 ( 1 ) & 0.931 \\
\hline$O(1)$ & $4563(6)$ & $8480(3)$ & $2265(1)$ & $12(1)$ & 1.966 \\
\hline$O(2)$ & $8340(7)$ & $7290(3)$ & $1882(2)$ & $17(1)$ & 1.797 \\
\hline$O(3)$ & $4237(6)$ & $6261(3)$ & $1941(2)$ & $15(1)$ & 1.924 \\
\hline$O(4)$ & $5042(6)$ & $7961(3)$ & $1177(1)$ & $15(1)$ & 2.229 \\
\hline$O(5)$ & $5496(6)$ & $8473(3)$ & $86(1)$ & $13(1)$ & 1.961 \\
\hline$O(6)$ & $1651(7)$ & $7439(3)$ & $496(2)$ & $17(1)$ & 1.947 \\
\hline$O(7)$ & $5579(6)$ & $6270(3)$ & $393(2)$ & $15(1)$ & 1.897 \\
\hline$O(8)$ & $851(7)$ & $948(3)$ & $1904(2)$ & $15(1)$ & 1.929 \\
\hline$O(9)$ & $-3342(7)$ & $912(3)$ & $1467(2)$ & $17(1)$ & 1.944 \\
\hline$O(10)$ & $325(7)$ & $237(3)$ & $809(2)$ & $16(1)$ & 1.906 \\
\hline$O(11)$ & $-397(7)$ & $2423(3)$ & $1064(2)$ & $18(1)$ & 2.176 \\
\hline$O(12)$ & $-522(7)$ & $4152(3)$ & $1841(2)$ & $13(1)$ & 1.970 \\
\hline$O(13)$ & $-182(6)$ & $4529(3)$ & $708(1)$ & $12(1)$ & 1.993 \\
\hline$O(14)$ & $3372(7)$ & $3582(3)$ & $1272(2)$ & $17(1)$ & 1.907 \\
\hline$O(15)$ & $1652(7)$ & $2438(3)$ & $3211(2)$ & $18(1)$ & 1.848 \\
\hline$O(16)$ & $5576(7)$ & 1315 (3) & $2939(2)$ & $16(1)$ & 1.909 \\
\hline$O(17)$ & $5259(6)$ & $3571(3)$ & $2753(2)$ & $14(1)$ & 1.941 \\
\hline$O(18)$ & $5361(6)$ & $2909(3)$ & $3803(2)$ & $16(1)$ & 2.144 \\
\hline$O(19)$ & $8357(7)$ & $2270(3)$ & $4576(2)$ & 18 (1) & 1.952 \\
\hline
\end{tabular}




$\begin{array}{lrllll}O(20) & 4255(6) & 1279(3) & 4581(2) & 15(1) & 2.039 \\ O(21) & 4642(6) & 3479(3) & 4901(2) & 15(1) & 1.978 \\ O(22) & 9362(7) & 9038(3) & 3136(2) & 14(1) & 1.945 \\ O(23) & 13362(7) & 8886(3) & 3710(2) & 17(1) & 1.872 \\ O(24) & 9453(6) & 9480(3) & 4267(2) & 12(1) & 2.033 \\ O(25) & 10118(7) & 7371(3) & 3913(2) & 18(1) & 2.245 \\ O(26) & 6603(7) & 6118(3) & 3626(2) & 18(1) & 1.912 \\ O(27) & 10633(7) & 5718(3) & 3102(2) & 14(1) & 1.874 \\ O(28) & 10271(6) & 5225(3) & 4219(2) & 14(1) & 1.857\end{array}$


Table 3. Selected bond lengths [ $[\AA]$ (up to $3.1 \AA$ ), angles [deg] as well as tetrahedral distortion parameters (quadratic elongation Q.E., angle variance A.V.) for $\mathrm{Na}_{6} \mathrm{Si}_{2} \mathrm{O}$.

\begin{tabular}{|c|c|c|c|}
\hline $\mathrm{Si}(1)-\mathrm{O}(3)$ & $1.615(4)$ & $\mathrm{Si}(1)-\mathrm{O}(2)$ & $1.618(4)$ \\
\hline $\mathrm{Si}(1)-\mathrm{O}(1)$ & $1.627(4)$ & $\mathrm{Si}(1)-\mathrm{O}(4)$ & $1.683(4)$ \\
\hline Q.E. $\quad 1.003$ & A.V. $\quad 14.00$ & & \\
\hline $\mathrm{Si}(2)-\mathrm{O}(6)$ & $1.595(4)$ & $\mathrm{Si}(2)-\mathrm{O}(7)$ & $1.603(4)$ \\
\hline $\mathrm{Si}(2)-\mathrm{O}(5)$ & $1.629(4)$ & $\mathrm{Si}(2)-\mathrm{O}(4)$ & $1.669(4)$ \\
\hline Q.E. 1.003 & A.V. $\quad 11.76$ & & \\
\hline $\mathrm{Si}(3)-\mathrm{O}(9)$ & $1.618(4)$ & $\mathrm{Si}(3)-0(8)$ & $1.620(4)$ \\
\hline $\mathrm{Si}(3)-0(10)$ & $1.623(4)$ & $\mathrm{Si}(3)-\mathrm{O}(11)$ & $1.667(4)$ \\
\hline Q.E. 1.002 & A.V. $\quad 8.80$ & & \\
\hline $\mathrm{Si}(4)-\mathrm{O}(12)$ & $1.605(4)$ & $\mathrm{Si}(4)-\mathrm{O}(14)$ & $1.605(5)$ \\
\hline $\operatorname{Si}(4)-O(13)$ & $1.623(4)$ & $\mathrm{Si}(4)-\mathrm{O}(11)$ & $1.672(4)$ \\
\hline Q.E. 1.003 & A.V. $\quad 13.98$ & & \\
\hline $\mathrm{Si}(5)-0(17)$ & $1.606(4)$ & $\mathrm{Si}(5)-O(15)$ & $1.610(4)$ \\
\hline $\mathrm{Si}(5)-\mathrm{O}(16)$ & $1.617(4)$ & $\mathrm{Si}(5)-\mathrm{O}(18)$ & $1.673(4)$ \\
\hline Q.E. 1.005 & A.V. $\quad 17.96$ & & \\
\hline $\operatorname{Si}(6)-0(19)$ & $1.590(4)$ & Si (6) -O (21) & $1.614(4)$ \\
\hline $\mathrm{Si}(6)-\mathrm{O}(20)$ & $1.617(4)$ & $\mathrm{Si}(6)-0(18)$ & $1.685(4)$ \\
\hline Q.E. 1.002 & A.V. $\quad 6.98$ & & \\
\hline $\mathrm{Si}(7)-\mathrm{O}(23)$ & $1.611(5)$ & $\mathrm{Si}(7)-\mathrm{O}(22)$ & $1.619(4)$ \\
\hline $\mathrm{Si}(7)-\mathrm{O}(24)$ & $1.620(4)$ & $\mathrm{Si}(7)-\mathrm{O}(25)$ & $1.664(4)$ \\
\hline Q.E. 1.003 & A.V. $\quad 10.49$ & & \\
\hline $\mathrm{Si}(8)-0(26)$ & $1.604(5)$ & Si (8) $-0(27)$ & $1.609(4)$ \\
\hline $\mathrm{Si}(8)-0(28)$ & $1.631(4)$ & $\mathrm{Si}(8)-\mathrm{O}(25)$ & $1.671(4)$ \\
\hline Q.E. 1.005 & A.V. $\quad 19.62$ & & \\
\hline $\mathrm{Na}(1)-\mathrm{O}(22)$ & $2.294(5)$ & $\mathrm{Na}(1)-\mathrm{O}(16) \# 8$ & $2.356(4)$ \\
\hline $\mathrm{Na}(1)-\mathrm{O}(1)$ & $2.432(4)$ & $\mathrm{Na}(1)-\mathrm{O}(9) \# 7$ & $2.452(5)$ \\
\hline $\mathrm{Na}(1)-\mathrm{O}(8) \# 7$ & $2.511(5)$ & & \\
\hline $\mathrm{Na}(2)-\mathrm{O}(23) \# 4$ & $2.257(5)$ & $\mathrm{Na}(2)-\mathrm{O}(16)$ & $2.344(5)$ \\
\hline $\mathrm{Na}(2)-\mathrm{O}(24) \# 2$ & $2.361(4)$ & $\mathrm{Na}(2)-\mathrm{O}(20)$ & $2.520(4)$ \\
\hline $\mathrm{Na}(2)-\mathrm{O}(22) \# 2$ & $2.658(4)$ & & \\
\hline $\mathrm{Na}(3)-\mathrm{O}(8)$ & $2.361(5)$ & $\mathrm{Na}(3)-\mathrm{O}(16)$ & $2.373(4)$ \\
\hline $\mathrm{Na}(3)-\mathrm{O}(22) \# 4$ & $2.383(5)$ & $\mathrm{Na}(3)-\mathrm{O}(1) \# 2$ & $2.406(4)$ \\
\hline $\mathrm{Na}(3)-\mathrm{O}(23) \# 4$ & $2.709(5)$ & $\mathrm{Na}(3)-\mathrm{O}(15)$ & $3.009(4)$ \\
\hline $\mathrm{Na}(4)-\mathrm{O}(9) \# 7$ & $2.230(4)$ & $\mathrm{Na}(4)-\mathrm{O}(4)$ & $2.276(4)$ \\
\hline $\mathrm{Na}(4)-\mathrm{O}(8) \# 8$ & $2.396(4)$ & $\mathrm{Na}(4)-\mathrm{O}(10) \# 8$ & $2.444(4)$ \\
\hline $\mathrm{Na}(4)-\mathrm{O}(1)$ & $2.533(5)$ & & \\
\hline $\mathrm{Na}(5)-\mathrm{O}(13) \# 10$ & $2.272(4)$ & $\mathrm{Na}(5)-\mathrm{O}(13)$ & $2.273(4)$ \\
\hline $\mathrm{Na}(5)-\mathrm{O}(7)$ & $2.311(4)$ & $\mathrm{Na}(5)-\mathrm{O}(7) \# 1$ & $2.334(4)$ \\
\hline $\mathrm{Na}(5)-\mathrm{O}(6)$ & $2.753(4)$ & & \\
\hline $\mathrm{Na}(6)-\mathrm{O}(20) \# 11$ & $2.331(4)$ & $\mathrm{Na}(6)-\mathrm{O}(24) \# 2$ & $2.371(4)$ \\
\hline $\mathrm{Na}(6)-\mathrm{O}(20)$ & $2.404(5)$ & $\mathrm{Na}(6)-\mathrm{O}(24) \# 9$ & $2.406(4)$ \\
\hline $\mathrm{Na}(6)-\mathrm{O}(19)$ & $2.504(5)$ & & \\
\hline
\end{tabular}




\begin{tabular}{|c|c|c|c|}
\hline $\mathrm{Na}(7)-\mathrm{O}(12) \# 6$ & $2.307(4)$ & $\mathrm{Na}(7)-\mathrm{O}(27)$ & $2.405(4)$ \\
\hline $\mathrm{Na}(7)-\mathrm{O}(17)$ & $2.406(5)$ & $\mathrm{Na}(7)-\mathrm{O}(3)$ & $2.546(5)$ \\
\hline $\mathrm{Na}(7)-\mathrm{O}(2)$ & $2.805(5)$ & $\mathrm{Na}(7)-\mathrm{O}(26)$ & $2.813(4)$ \\
\hline $\mathrm{Na}(8)-\mathrm{O}(14)$ & $2.329(4)$ & $\mathrm{Na}(8)-\mathrm{O}(7)$ & $2.414(5)$ \\
\hline $\mathrm{Na}(8)-\mathrm{O}(3)$ & $2.423(4)$ & $\mathrm{Na}(8)-\mathrm{O}(13) \# 6$ & $2.503(4)$ \\
\hline $\mathrm{Na}(8)-\mathrm{O}(12) \# 6$ & $2.632(5)$ & & \\
\hline $\mathrm{Na}(9)-\mathrm{O}(2) \# 3$ & $2.264(5)$ & $\mathrm{Na}(9)-\mathrm{O}(27) \# 3$ & $2.377(5)$ \\
\hline $\mathrm{Na}(9)-\mathrm{O}(1)$ & $2.406(4)$ & $\mathrm{Na}(9)-\mathrm{O}(22) \# 3$ & $2.556(4)$ \\
\hline $\mathrm{Na}(9)-\mathrm{O}(3)$ & $2.572(4)$ & & \\
\hline $\mathrm{Na}(10)-\mathrm{O}(21)$ & $2.272(4)$ & $\mathrm{Na}(10)-\mathrm{O}(28)$ & $2.306(5)$ \\
\hline $\mathrm{Na}(10)-\mathrm{O}(28) \# 3$ & $2.343(4)$ & $\mathrm{Na}(10)-\mathrm{O}(21) \# 5$ & $2.387(4)$ \\
\hline $\mathrm{Na}(11)-\mathrm{O}(10) \# 14$ & $2.278(4)$ & $\mathrm{Na}(11)-\mathrm{O}(5) \# 2$ & $2.323(4)$ \\
\hline $\mathrm{Na}(11)-\mathrm{O}(5) \# 1$ & $2.338(4)$ & $\mathrm{Na}(11)-\mathrm{O}(10) \# 6$ & $2.507(5)$ \\
\hline $\mathrm{Na}(12)-\mathrm{O}(6) \# 10$ & $2.221(4)$ & $\mathrm{Na}(12)-\mathrm{O}(11)$ & $2.386(5)$ \\
\hline $\mathrm{Na}(12)-\mathrm{O}(5) \# 1$ & $2.393(4)$ & $\mathrm{Na}(12)-\mathrm{O}(7) \# 1$ & $2.490(5)$ \\
\hline $\mathrm{Na}(12)-\mathrm{O}(13)$ & $2.595(4)$ & & \\
\hline $\mathrm{Na}(13)-\mathrm{O}(1)$ & $2.302(4)$ & $\mathrm{Na}(13)-\mathrm{O}(23) \# 3$ & $2.342(4)$ \\
\hline $\mathrm{Na}(13)-\mathrm{O}(22)$ & $2.352(4)$ & $\mathrm{Na}(13)-\mathrm{O}(26)$ & $2.356(5)$ \\
\hline $\mathrm{Na}(14)-\mathrm{O}(15) \# 6$ & $2.345(5)$ & $\mathrm{Na}(14)-\mathrm{O}(12) \# 6$ & $2.424(5)$ \\
\hline $\mathrm{Na}(14)-\mathrm{O}(8) \# 6$ & $2.485(4)$ & $\mathrm{Na}(14)-\mathrm{O}(17)$ & $2.511(4)$ \\
\hline $\mathrm{Na}(14)-\mathrm{O}(16)$ & $2.612(5)$ & & \\
\hline $\mathrm{Na}(15)-\mathrm{O}(12)$ & $2.247(4)$ & $\mathrm{Na}(15)-\mathrm{O}(17)$ & $2.265(4)$ \\
\hline $\mathrm{Na}(15)-\mathrm{O}(3)$ & $2.269(4)$ & $\mathrm{Na}(15)-\mathrm{O}(27) \# 3$ & $2.328(4)$ \\
\hline $\mathrm{Na}(15)-\mathrm{O}(14)$ & $2.869(4)$ & & \\
\hline $\mathrm{Na}(16)-\mathrm{O}(19) \# 3$ & $2.264(5)$ & $\mathrm{Na}(16)-\mathrm{O}(25) \# 5$ & $2.314(4)$ \\
\hline $\mathrm{Na}(16)-\mathrm{O}(21)$ & $2.402(4)$ & $\mathrm{Na}(16)-\mathrm{O}(20)$ & $2.425(4)$ \\
\hline $\mathrm{Na}(16)-\mathrm{O}(24) \# 5$ & $2.497(4)$ & & \\
\hline $\mathrm{Na}(17)-\mathrm{O}(14)$ & $2.246(4)$ & $\mathrm{Na}(17)-\mathrm{O}(5) \# 1$ & $2.317(4)$ \\
\hline $\mathrm{Na}(17)-\mathrm{O}(11) \# 6$ & $2.396(5)$ & $\mathrm{Na}(17)-\mathrm{O}(9) \# 6$ & $2.409(5)$ \\
\hline $\mathrm{Na}(18)-\mathrm{O}(10) \# 7$ & $2.249(4)$ & $\mathrm{Na}(18)-\mathrm{O}(6) \# 6$ & $2.294(5)$ \\
\hline $\mathrm{Na}(18)-\mathrm{O}(4)$ & $2.376(4)$ & $\mathrm{Na}(18)-\mathrm{O}(2)$ & $2.439(5)$ \\
\hline $\mathrm{Na}(19)-\mathrm{O}(14)$ & $2.308(5)$ & $\mathrm{Na}(19)-\mathrm{O}(9) \# 6$ & $2.314(4)$ \\
\hline $\mathrm{Na}(19)-\mathrm{O}(8)$ & $2.417(4)$ & $\mathrm{Na}(19)-\mathrm{O}(17)$ & $2.563(4)$ \\
\hline $\mathrm{Na}(19)-\mathrm{O}(16)$ & $2.627(5)$ & & \\
\hline $\mathrm{Na}(20)-\mathrm{O}(26)$ & $2.245(5)$ & $\mathrm{Na}(20)-\mathrm{O}(18)$ & $2.390(4)$ \\
\hline $\mathrm{Na}(20)-\mathrm{O}(27) \# 3$ & $2.433(5)$ & $\mathrm{Na}(20)-\mathrm{O}(28) \# 3$ & $2.527(4)$ \\
\hline $\mathrm{Na}(20)-\mathrm{O}(17)$ & $2.551(4)$ & & \\
\hline $\mathrm{Na}(21)-\mathrm{O}(2) \# 3$ & $2.325(4)$ & $\mathrm{Na}(21)-\mathrm{O}(6)$ & $2.393(4)$ \\
\hline $\mathrm{Na}(21)-\mathrm{O}(3)$ & $2.460(4)$ & $\mathrm{Na}(21)-\mathrm{O}(13)$ & $2.486(4)$ \\
\hline $\mathrm{Na}(21)-\mathrm{O}(12)$ & $2.802(5)$ & & \\
\hline $\mathrm{Na}(22)-\mathrm{O}(20)$ & $2.311(4)$ & $\mathrm{Na}(22)-\mathrm{O}(15)$ & $2.318(5)$ \\
\hline $\mathrm{Na}(22)-\mathrm{O}(19) \# 3$ & $2.333(4)$ & $\mathrm{Na}(22)-\mathrm{O}(24) \# 4$ & $2.335(4)$ \\
\hline $\mathrm{Na}(23)-\mathrm{O}(21) \# 5$ & $2.294(4)$ & $\mathrm{Na}(23)-\mathrm{O}(26)$ & $2.299(4)$ \\
\hline $\mathrm{Na}(23)-\mathrm{O}(25) \# 3$ & $2.375(5)$ & $\mathrm{Na}(23)-\mathrm{O}(23) \# 3$ & $2.426(4)$ \\
\hline $\mathrm{Na}(24)-\mathrm{O}(15) \# 6$ & $2.260(4)$ & $\mathrm{Na}(24)-\mathrm{O}(28)$ & $2.322(4)$ \\
\hline $\mathrm{Na}(24)-\mathrm{O}(18)$ & $2.372(4)$ & $\mathrm{Na}(24)-\mathrm{O}(19)$ & $2.440(5)$ \\
\hline
\end{tabular}




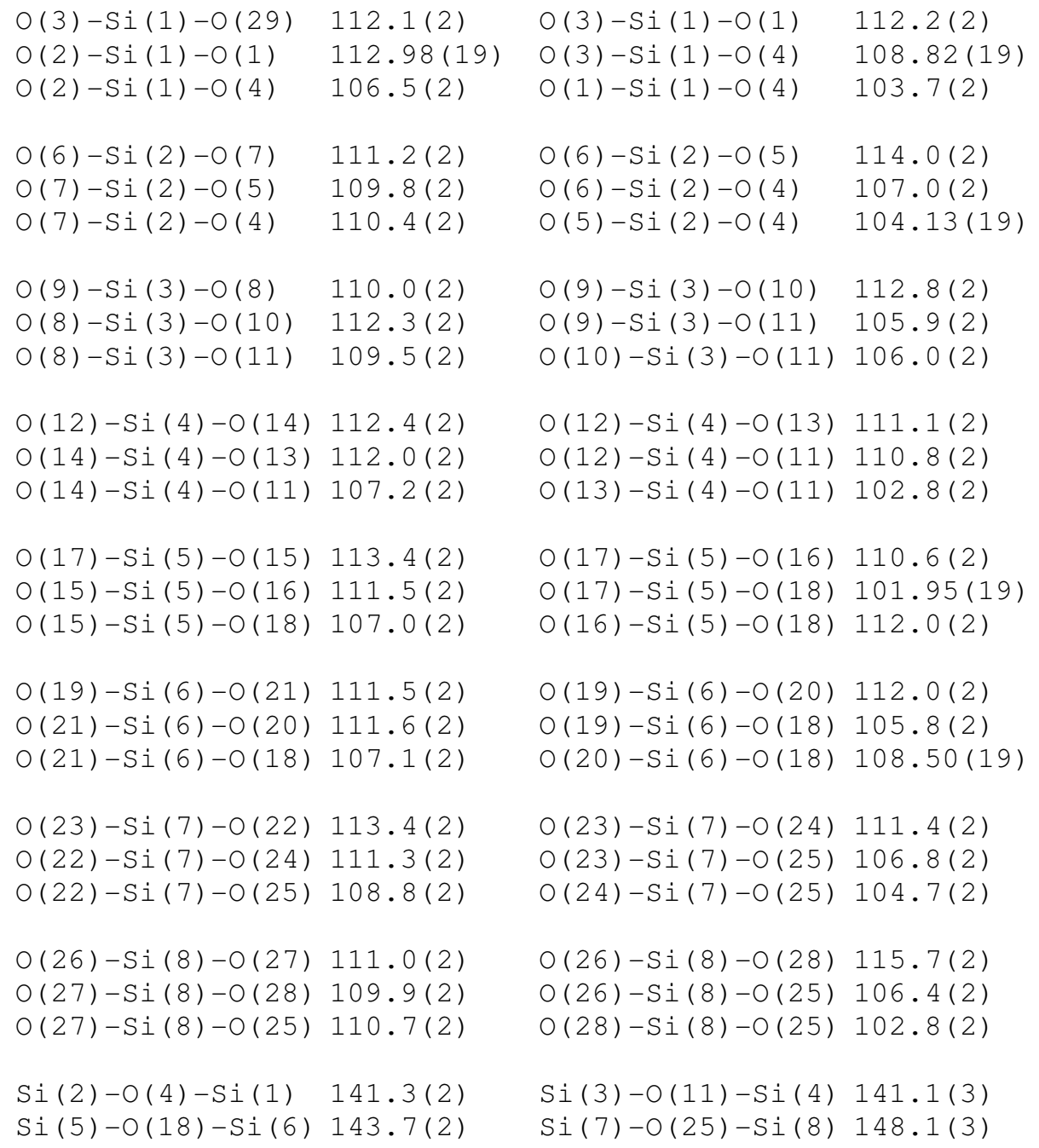

Symmetry transformations used to generate equivalent atoms:

$\begin{array}{lll}\# 1-x+1,-y+1,-z & \# 2 x, y-1, z & \# 3 x-1, y, z \\ \# 4 x-1, y-1, z & \# 5-x+1,-y+1,-z+1 & \# 6 x+1, y, z \\ \# 7 x+1, y+1, z & \# 8 x, y+1, z & \# 9-x+2,-y+1,-z+1 \\ \# 10-x,-y+1,-z & \# 11-x+1,-y,-z+1 & \# 12-x+2,-y,-z+1\end{array}$


Table 4. Anisotropic displacement parameters $\left(\AA^{2} \times 10^{3}\right)$ for the non-oxygen atoms in $\mathrm{Na}_{6} \mathrm{Si}_{2} \mathrm{O}_{7}$. The

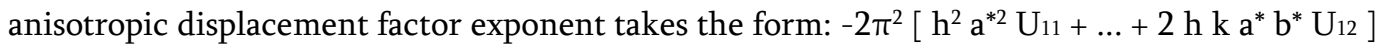

\begin{tabular}{|c|c|c|c|c|c|c|}
\hline & $\mathrm{U}_{11}$ & $\mathrm{U}_{22}$ & $\mathrm{U}_{33}$ & $\mathrm{U}_{23}$ & $\mathrm{U}_{13}$ & $\mathrm{U}_{12}$ \\
\hline Si(1) & $6(1)$ & $11(1)$ & $9(1)$ & $-1(1)$ & $-1(1)$ & $0(1)$ \\
\hline Si (2) & $7(1)$ & $12(1)$ & $7(1)$ & $-1(1)$ & $-1(1)$ & $0(1)$ \\
\hline Si (3) & $6(1)$ & $10(1)$ & $12(1)$ & $2(1)$ & $-1(1)$ & $-1(1)$ \\
\hline Si(4) & $7(1)$ & $8(1)$ & $9(1)$ & $1(1)$ & $-2(1)$ & $0(1)$ \\
\hline Si (5) & $5(1)$ & $12(1)$ & $10(1)$ & $-1(1)$ & $0(1)$ & $1(1)$ \\
\hline Si (6) & $9(1)$ & $10(1)$ & $9(1)$ & $2(1)$ & $-2(1)$ & $-2(1)$ \\
\hline Si (7) & $5(1)$ & $10(1)$ & $10(1)$ & $2(1)$ & $-1(1)$ & $-2(1)$ \\
\hline Si (8) & $6(1)$ & $10(1)$ & $10(1)$ & $1(1)$ & $-2(1)$ & $-1(1)$ \\
\hline $\mathrm{Na}(1)$ & $8(1)$ & $19(1)$ & $14(1)$ & $3(1)$ & $-1(1)$ & $-2(1)$ \\
\hline $\mathrm{Na}(2)$ & $9(1)$ & $18(1)$ & $19(1)$ & $0(1)$ & $-3(1)$ & $-3(1)$ \\
\hline $\mathrm{Na}(3)$ & $9(1)$ & $20(1)$ & $22(1)$ & $2(1)$ & $0(1)$ & $-3(1)$ \\
\hline $\mathrm{Na}(4)$ & $9(1)$ & $17(1)$ & $25(1)$ & $0(1)$ & $-6(1)$ & $-4(1)$ \\
\hline $\mathrm{Na}(5)$ & $11(1)$ & $19(1)$ & $12(1)$ & $2(1)$ & $-1(1)$ & $-2(1)$ \\
\hline $\mathrm{Na}(6)$ & $13(2)$ & $13(1)$ & $20(1)$ & $2(1)$ & $-3(1)$ & $-3(1)$ \\
\hline $\mathrm{Na}(7)$ & $11(2)$ & $21(1)$ & $16(1)$ & $-1(1)$ & $-2(1)$ & $1(1)$ \\
\hline $\mathrm{Na}(8)$ & $16(1)$ & $18(1)$ & $17(1)$ & $0(1)$ & $2(1)$ & $-1(1)$ \\
\hline $\mathrm{Na}(9)$ & $11(1)$ & $22(1)$ & $14(1)$ & $2(1)$ & $0(1)$ & $-5(1)$ \\
\hline $\mathrm{Na}(10)$ & $9(1)$ & $18(1)$ & $16(1)$ & $2(1)$ & $-1(1)$ & $0(1)$ \\
\hline $\mathrm{Na}(11)$ & $11(2)$ & $21(1)$ & $15(1)$ & $1(1)$ & $1(1)$ & $-1(1)$ \\
\hline $\mathrm{Na}(12)$ & $7(1)$ & $36(2)$ & $18(1)$ & $-8(1)$ & $2(1)$ & $-1(1)$ \\
\hline $\mathrm{Na}(13)$ & $12(1)$ & $18(1)$ & $16(1)$ & $1(1)$ & $-2(1)$ & $-1(1)$ \\
\hline $\mathrm{Na}(14)$ & $8(1)$ & $23(1)$ & $20(1)$ & $0(1)$ & $2(1)$ & $-3(1)$ \\
\hline $\mathrm{Na}(15)$ & $13(2)$ & $20(1)$ & $15(1)$ & $1(1)$ & $-1(1)$ & $-1(1)$ \\
\hline $\mathrm{Na}(16)$ & $12(1)$ & $23(1)$ & $14(1)$ & $-1(1)$ & $3(1)$ & $-6(1)$ \\
\hline $\mathrm{Na}(17)$ & $21(1)$ & $28(1)$ & $14(1)$ & $-1(1)$ & $-7(1)$ & $6(1)$ \\
\hline $\mathrm{Na}(18)$ & $16(1)$ & $20(1)$ & $24(1)$ & $0(1)$ & $4(1)$ & $-8(1)$ \\
\hline $\mathrm{Na}(19)$ & $15(1)$ & $18(1)$ & $16(1)$ & $0(1)$ & $2(1)$ & $0(1)$ \\
\hline $\mathrm{Na}(20)$ & $12(1)$ & $20(1)$ & $27(1)$ & $-2(1)$ & $-1(1)$ & $-1(1)$ \\
\hline $\mathrm{Na}(21)$ & $17(1)$ & $16(1)$ & $22(1)$ & $0(1)$ & $-2(1)$ & $-1(1)$ \\
\hline $\mathrm{Na}(22)$ & $11(1)$ & $16(1)$ & $19(1)$ & $2(1)$ & $1(1)$ & $-1(1)$ \\
\hline $\mathrm{Na}(23)$ & $25(2)$ & $22(1)$ & $20(1)$ & $3(1)$ & $-7(1)$ & $7(1)$ \\
\hline $\mathrm{Na}(24)$ & $20(2)$ & $13(1)$ & $30(1)$ & $-2(1)$ & $8(1)$ & $-4(1)$ \\
\hline
\end{tabular}




\section{Figure captions}

Figure 1. Zig-zag arrangement of the $\left[\mathrm{Si}_{2} \mathrm{O}_{7}\right]$-units in (a) $\mathrm{Na}_{6} \mathrm{Si}_{2} \mathrm{O}_{7}$, (b) $\mathrm{Li}_{6} \mathrm{Si}_{2} \mathrm{O}_{7}$, (c) $\mathrm{K}_{6} \mathrm{Si}_{2} \mathrm{O}_{7}$ and (d) $\mathrm{Ag}_{6} \mathrm{Si}_{2} \mathrm{O}_{7}$ (form II ). The $\mathrm{Si}$-Si vectors for two dimers in $\mathrm{Na}_{6} \mathrm{Si}_{2} \mathrm{O}_{7}$ belonging to two subsequent layers of the ... $\mathrm{ABAB} \ldots$ sequence are indicated by arrows.

Figure 2. Side view of the whole structure of $\mathrm{Na}_{6} \mathrm{Si}_{2} \mathrm{O}_{7}$. Light grey $\left[\mathrm{Si}_{2} \mathrm{O}_{7}\right]$-dimers and medium grey $\left[\mathrm{NaO}_{4}\right]$-tetrahedra form a network in which additional sodium cations (dark grey spheres) are incorporated. 


\section{References}

[1] F.C. Kracek, J. Phys. Chem. 1930, 34, 1583.

[2] J. D’Ans, J. Löffler, Z. Anorg. Allg. Chem. 1930, 191, 1.

[3] E. Zintl, W. Morawietz, Z. Anorg. Allg. Chem. 1938, 236, 372.

[4] E. Zintl, H. Leverkus, Z. Anorg. Allg. Chem. 1939, $243,1$.

[5] J. Löffler, Glastechn. Ber. 1969, 42, 92.

[6] A.I. Zaitsev, N.E. Shelkova, N.P. Lyakishev, B.M. Mogutnov, Phys Chem. Chem. Phys. 1999, 1, 1899.

[7] M. Rys, Dissertation, RWTH Aachen, 2007.

[8] K. Kautz, G. Müller, W. Schneider, Glastechn. Ber. 1970, 43, 377.

[9] R.L. Schmid, J. Felsche, Thermochim. Acta 1983, 71, 359.

[10] A.J.C. Wilson (ed.), International Tables for Crystallography, Volume C, Kluwer Academic, Dordrecht, 1995.

[11] M.C. Burla, M. Camalli, B. Carrozzini, G.L. Cascarano, C. Giacovazzo, G. Polidori, R. Spagna, J. Appl. Cryst. 2003, 36, 1103.

[12] G.M. Sheldrick, Acta Cryst. 2008, A64, 112.

[13] A.L. Spek, PLATON: A multipurpose crystallographic tool, Utrecht University, Utrecht, The Netherlands.

[14] W.S. McDonald, D.W.J. Cruickshank, Acta Cryst. 1967, 22, 37.

[15] K. Robinson, G.V. Gibbs, P.H. Ribbe, Science 1971, 172, 567.

[16] N.E. Brese, M. O’Keeffe, Acta Cryst. 1991, B42, 191.

[17] A. Salinas-Sanchez, J.L. Garcia-Muñoz, J. Rodriguez-Carvajal, R. Saez-Puche, J.L. Martinez, J. Solid State Chem. 1992, 100, 201.

[18] I.D. Brown, The Chemical Bond in Inorganic Chemistry, Oxford University Press, Oxford, 2002.

[19] M. Jansen, Z. Kristallogr. 1982, 160, 127.

[20] C. Hoch, C. Röhr, Z. Naturforsch. 2001, B56, 423.

[21] H. Völlenkle, A. Wittmann, H. Nowotny, Mh. Chem. 1969, 100, 295.

[22] C. Linke, M. Jansen, Z. Anorg. Allg. Chem. 1996, 622, 486.

[23] M. Monz, D. Ostermann, H. Jacobs, J. Alloys Comp. 1993, 200, 211. 
[24] J. Kissel., R. Hoppe, J. Less-Common Met. 1990, 158, 327.

[25] M. Jansen, R. Hoppe, Naturwiss. 1973, 60, 104. 
(a) $Y \stackrel{\text { Y }}{Y}: Y Y$ MYMYM T.4. 12 MTHYS $X a X \nabla^{b} X$

(c) $X+x \rightarrow X$

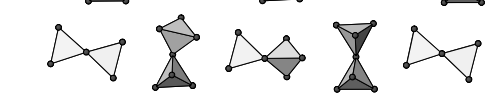

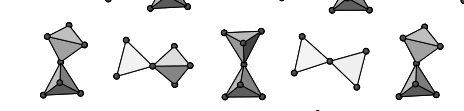

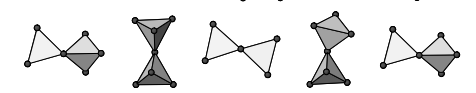
$x \rightarrow x \rightarrow x$

(b) $X: x: x$ $\therefore X: X:$

$x: \therefore: \therefore x$

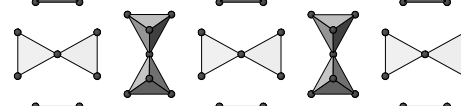
$x: x: x$

(d) $Y \not Y \not Y$

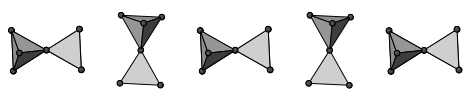
$Y>Y>Y$ $\triangle X N X N$ $Y>Y>Y$ 


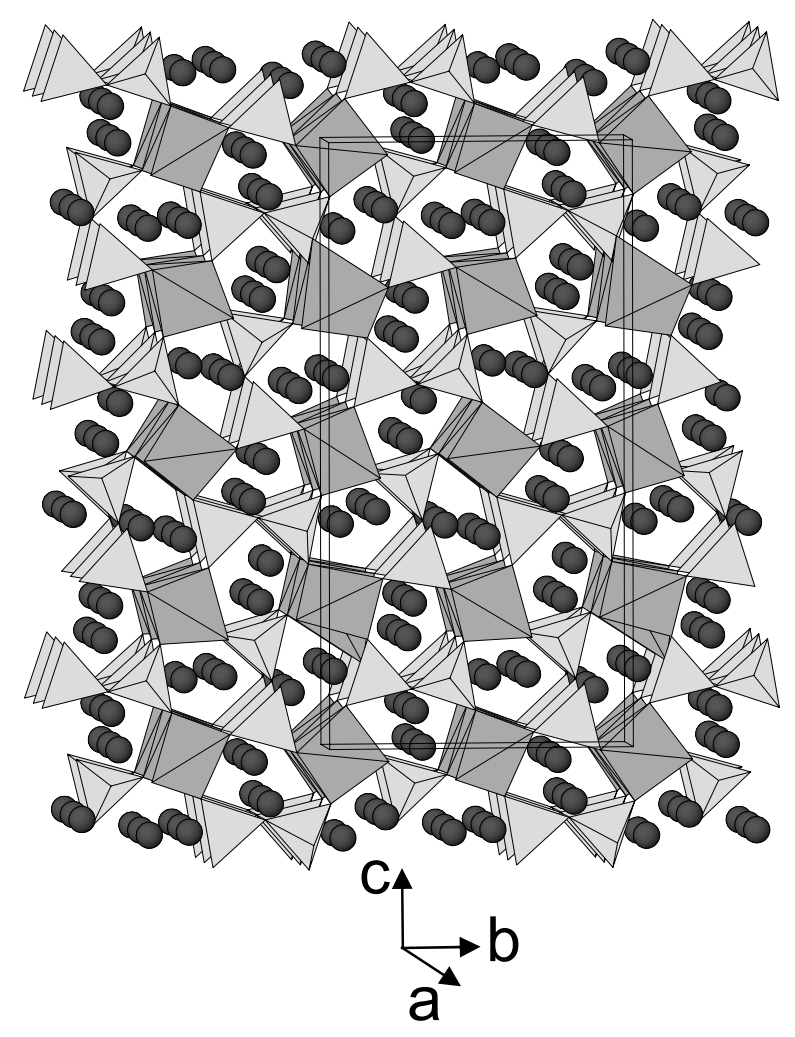

